\title{
Digital José Juan Tablada and the genesis of a hyper reading*
}

Rodolfo Mata ${ }^{a}$

\begin{abstract}
This essay describes how the development of two digital projects dealing with the works of the Mexican poet José Juan Tablada affected the nature of the reading and writing practices of the author and other participants. The first project, produced in the years of 1997 and 1998, comprises two CD-ROM's with two important sets of journalistic chronicles: La Babilonia de Hierro. Crónicas neoyorquinas (1920-1936) (724 chronicles) and México de Día y de Noche. Crónicas mexicanas (1928-1943) (399 chronicles). The second one resulted in another CDROM, José Juan Tablada: letra e imagen (poesía, prosa, obra gráfica y varia documental (2003), which included Tablada's graphic archive, his four visual poetry books and other works involving the relationship between word and image. The project also includes a website (www. tablada.unam.mx). The author points out how automated text searches provided by the first $C D^{\prime}$ s helped in the annotation process of the graphic archive pieces - which encompass watercolors; pencil, charcoal and ball pen drawings; photographs and clippings from reviews and journals - , and how the careful observation of these images revealed information of Tablada's life and works. This information had remained unattended because the pieces of the archive had been considered almost exclusively in their visual dimension rather than in relation with the literary realm. The author discusses the three modalities of reading close, hyper and machine reading - proposed by N. Katherine Hayles, in How We Think (2012), and shows how Tablada's digital research projects lead to practice the two latter reading modalities in a natural and unperceived way. The recollection of the whole experience also demonstrated that hyper reading promoted by the construction of the website resulted in mnemonic modifications that linked the graphic archive images to Tablada's biographical discourse.
\end{abstract}

Keywords: Digital Humanities, Latin-American Literature, Mexican Poetry, Visual Poetry

Recebido em 29 de março de 2016 Aceito em 13 de abril de 2016

Investigaciones

Bibliográficas

(forthcoming).

a Pesquisador da UNAM/Instituto de Investigaciones Filológicas, rmata2009@yahoo.com.mx. 
The story I am going to tell is clearly a personal experience, but nevertheless valid in the context of serious literary research. I present it here with the hope that, what I read not so long ago, is being practiced and supported by numerous colleagues inside the academy. Personal experiences have the force of testimony and can guide the process of scientific inference; full of tumbles, doubts, illusions and deceptions, experiences cannot be relegated in favor of deductive and schematic presentation strategies that only show well organized results placed in conceptual compartments. For that reason, in an initial "act of disobedience", I do not cite the article where I read about this vindication, simply because I don't remember the bibliographical data involved, I just recall the idea. I looked around for it several times until I began to feel that I was losing something much more valuable than the technical reference: time. I do not mean, of course, to exempt myself of the duty of giving credit to whom it corresponds. But being such a general impression, I refer myself to my own experience and to other similar experiences which I see are being shared.

My relation with the works of José Juan Tablada through academic research is nowadays deep and broad. It began in the years of 1997 and 1998, with the preparation and production of two CD-ROMs that offer two very important sets of journalistic chronicles written by the poet. La Babilonia de Hierro. Crónicas neoyorquinas (1920-1936) (724 chronicles) and México de Día y de Noche. Crónicas mexicanas (1928-1943) (399 chronicles) received the support of the Centro Nacional Editor de Discos Compactos, Colima (CENEDIC) in Mexico. The basic idea behind the project was to offer automated text search that implied the expansion of the concepts of index and database. The production of the disks required a thorough reading of the texts, collating their transcription with photocopies of the original newspapers, making the necessary corrections, and revising and enlarging the notes made by the authors that furnished us the initial typing and the preliminary studies, namely Esther Hernández Palacios and Pilar Mandujano Jacobo. Also, it was necessary to "mark" the texts with hidden special characters destined to be detected by CENEDIC's technical team, in order to introduce correctly the pertinent typographic distinctions (bold and italic fonts) and textual elements of each chronicle (titles, subtitles, hemerographic data and notes). In those days, CD-ROMs 
${ }^{1}$ The Archivo José Juan Tablada of the Instituto de Investigaciones Filológicas is organized in the following sections: I. Graphic materials, II. Diary and memoires, III. Correspondence, IV. Personal and familiar documents, V. Poetry, VI. Prose, VII. Drama and VIII. Hemerography. The webpage Archivo Gráfico José Juan Tablada shows the section I. Graphic materials, including watercolors, pencil and ball pen drawings, photographs and clippings of periodicals. The organization of the webpage follows the Catálogo del Archivo José Juan Tablada, unpublished and still being reviewed. were the data storage technology $d u$ jour, and it was not yet supplanted by the emerging internet universe.

At the same time, the experience with the project of the virtual anthology Horizonte de Poesía Mexicana, launched in 1996, one of the first of this genre, opened the possibility of formulating a new academic research project about Tablada's work. Two pilot websites were launched and finally a third CD-ROM was produced: José Juan Tablada: Letra e imagen_(poesía, prosa, obra gráfica y varia documental) (2003). The disk includes electronic versions of the four books of visual poetry written by Tablada - Un día... Poemas sintéticos (1919), Li po y otros poemas (1920), El jarro de flores. Disociaciones líricas (1922) y La feria. Poemas mexicanos (1928) -; the volume Hiroshigué: el pintor de la nieve y de la lluvia, de la noche y de la luna (1914); the complete digitalization of the author's graphic archive, ${ }^{1}$ with each piece annotated; and the electronic edition of the complete poetry of Tablada - with the exception of the calligrammatic poemsusing a peculiar reading system named Poesía Densa, created by Diego Bonilla. The disk is provided with a search engine for all the text included. The initial websites were finally merged into one entitled José Juan Tablada: letra e imagen, that offers a great part of the information of the CD-ROM, and has received several updates, such as the inclusion of a pdf version of En el país del sol -book in which Tablada organized his Japanese chronicles, previously published in the Revista Moderna- and the branched website that contains Tablada's ukiyo-e collection, namely Colección de estampas japonesas de José Juan Tablada en la Biblioteca Nacional.

The making of this third compact disk was a complicated process that summed up the previous experiences. The possibility of creating a hypertext around the figure of Tablada and his graphic archive appeared as an opportunity to construct a real network of crossed references and a chance for putting into practice the promises of collaborative work via internet. Unfortunately, we were able to realize only part of our goals. Most of the hypertext cross-references were suggested or done by me, because few of the researchers who were participating in the annotation process really showed themselves interested in the new mode of reading and, in consequence, few consulted all the pieces of the graphic archive in the pilot websites designed for that purpose. On the contrary, the concept of Poesía Densa 
was fully developed based on the characteristics of the digital medium. Diego Bonilla and I collaborated fully on a remote basis sending and receiving emails and archives via ftp from Mexico City to Sacramento, California, and vice versa. The technology for videoconference had not been developed yet for the consumer market, and Skype and other communication tools did not exist. In fact, it was surprising that we only came to meet each other personally until 2011. Professor Bonilla's idea was a new reading system that consisted in creating a map of the vocabulary contained in the poetic corpus of Tablada's oeuvre in order to "travel" through the several apparitions of each word in the different contexts given by the poems. For a better appreciation of this project, I invite the reader to consult it in the mentioned webpage. ${ }^{2}$

The annotation process was a very special one. Several images of the graphic archive -that encompasses watercolors; pencil, charcoal and ball pen drawings; photographs and clippings from reviews and journals - appeared to the annotation team as challenging enigmas (see images 1-3).

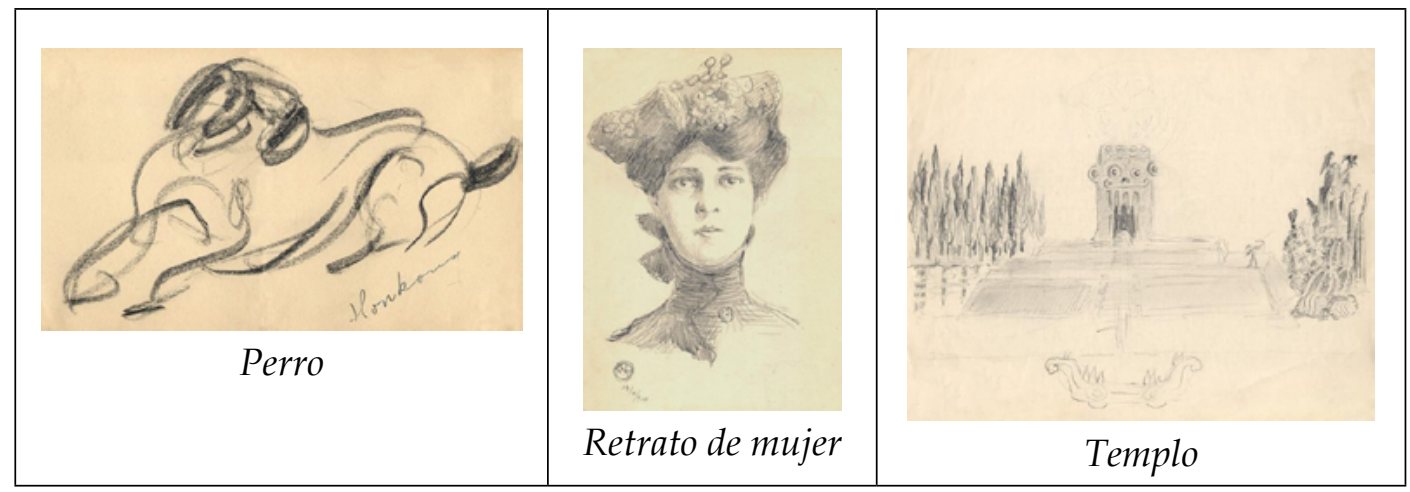

Images 1-3: Perro; Retrato de mujer; Templo. Archivo José Juan Tablada.

The catalog records that were realized by Columba Galván Gaytán sometimes offered insufficient or wrong data. In the annotation process and in the crossing of information we used not only the indexes of the volumes of the collection "Obras de José Juan Tablada", of the UNAM, and other bibliographical

${ }^{2}$ http://www.tablada. u $n$ a $m . m x / . \quad$ Th $\mathrm{e}$
corresponding section should be consulted in browsers such as Firefox or Explorer that allow the use of the Shockwave plugin. sources, but also the compact disks, the searching possibilities brought in by the typing of the complete poetry made for the section Poesía Densa, and other internet resources. For example, the charcoal drawing entitled Perro [Dog], originally had an annotation of the poet, that was read as "Honbonn" by 
Galván Gaytán. Only after reading the book José Juan Tablada en la intimidad, memoirs of Nina Cabrera de Tablada, the poet's widow -where she refers the deep loving feelings his husband had towards animals - and finding the watercolor named Honkong nuestro perro [Honkong our dog] -another piece of the archive-, we were able to decipher the annotation with complete certainty and to contextualize its elaboration. On the contrary, the pencil drawings Retrato de mujer [Portrait of a woman] and Templo [Temple] remain as enigmas, even though there are some clues to trail their possible referents.

Only today, after 12 years, I realize that the annotation task of the graphic archive compelled me to read the life and works of Tablada in a peculiar way, radically different than before. The contact with its images and with the tacit or implied connections of them with textual sources and/or image sources - available or not via electronic media- created a different memory structure in me. During the process, whenever possible, we made annotations that included images, a practice that was somewhat unusual in the paper universe, generally due to the involved costs. The digitalization of images with these purposes, using scanners rather than photographic cameras, was only beginning to be common. I remember, for example, shooting digital photographs with a camera that worked with $1.44 \mathrm{MB}$ diskettes, a technology that is completely obsolete today.

From the annotation process emerged several facts in the life and works of Tablada that were unknown or had received little attention, especially because they remained among a universe of other images or because they were mostly considered visual, rather than literary, artifacts. I will mention several of these facts, organizing them by categories:

1. José Juan Tablada as a poet-painter. Tablada pretended to dedicate himself professionally to painting and even frequented, in 1905, the atelier of Antonio Fabrés, chief the Mexican school of painting, the Academia de San Carlos, from 1903 to 1906. The traces of this truncated vocation can be found in the graphic archive and range from childhood drawings to splendid watercolors, such as the entitled Mazatlán desde el Cerro del Faro (1894), Puerta del Jardín de Thé en Golden Gate Park (1900) and Yokohama (1900) (see images 4-6). The drawings 
that he realized as a naturalist are also notable, especially those related with his interests in entomology, or the ones that were collected in the posthumous volume Hongos mexicanos comestibles. Micología económica (1983), or those included in the book Un día... Poemas sintéticos. In the essay "José Juan Tablada: la escritura iluminada por la imagen", that I wrote as an introduction to the CD-ROM José Juan Tablada: letra e imagen, I make a revision of these and other aspects of Tablada's pictorial vocation.

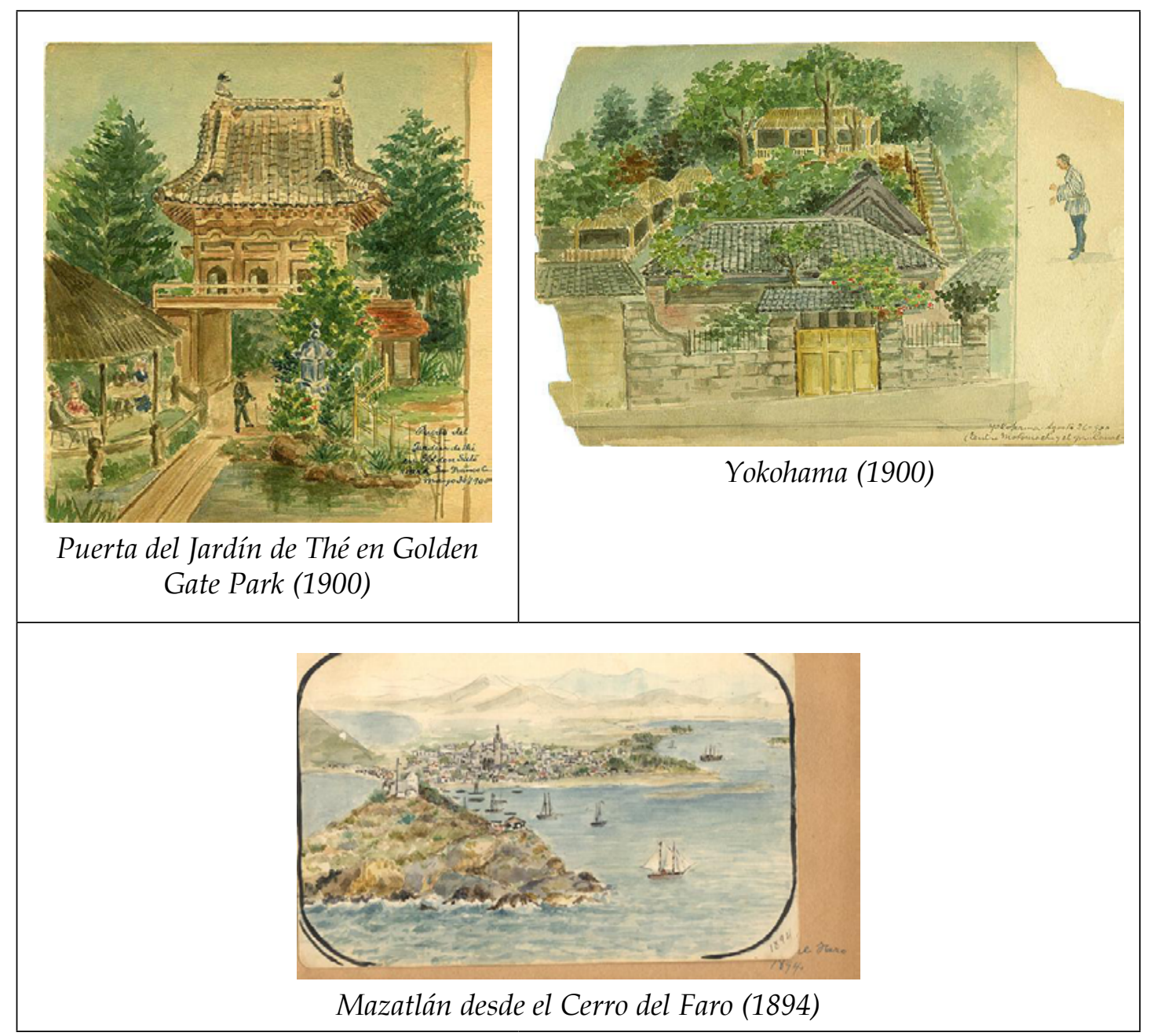

Images 4-6: Mazatlán desde el Cerro del Faro (1894); Puerta del Jardín de Thé en Golden Gate Park (1900); Yokohama (1900). Archivo José Juan Tablada.

2. Discovery of a haiku. The text that appears with the watercolor entitled Oruga de thrydopterix ephemeraeformis - Churruscos was never considered before as a haiku even though it has all the necessary characteristics to be one: 
"Parece un dragón chino revestido / con gualdrapa de seda...". ${ }^{3}$ In spite of its 18 syllables, distributed in 2 verses -compared with the 17 syllables in 3 verses of the traditional rigorous parameters-, we can judge it as a haiku, because we know that Tablada frequently allowed himself this type of poetic licenses in the genre (see image 7).

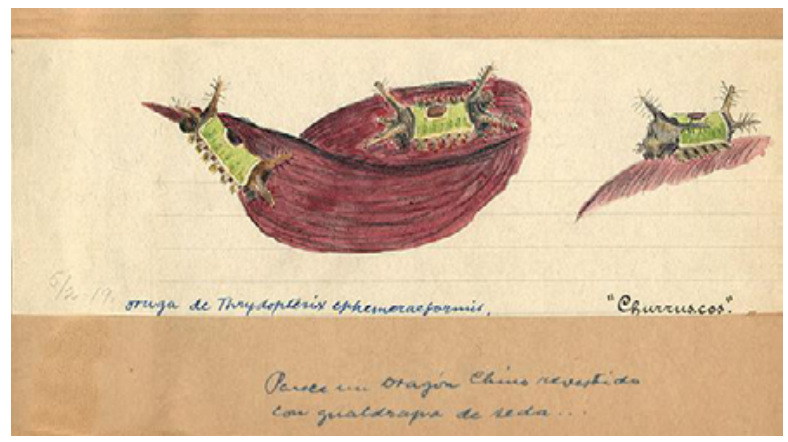

Imagen 7: Oruga de thrydopterix ephemeraeformis. Archivo José Juan Tablada.

The use of the scientific name in "Churruscos" as part of the poetic composition is a practice that has precedents. We can also find a scientific name in "Palma real", another haiku included in El jarro de flores, in which it appears as a footnote that specifies "Oreodoxa regia". Maybe the scientific name of "Churruscos" would have ended, in the printed poem, as a footnote. It is possible that Tablada did not publish "Churruscos" because he was not satisfied with the text, in what refers to the literary image, the theme or the global conception of the poem's effect; or merely because it did not fit in the structure of any of his haiku books. Nevertheless, it fulfills the requirements of brevity, grace and humor, and has another desirable feature: that of accomplishing representation by following the idea of maxima in minima that Tablada repeated frequently. A big and boastful Chinese dragon can be seen in a tiny and trivial caterpillar.

3 It looks like a Chinese dragon dressed / with a silk horse blanket...

\section{Discovery of original images that corresponded to haikus} in $E l$ jarro de flores (1922). In the graphic archive, the colored pencils drawing Hormigas sobre un grillo muerto has, by its side, in handwriting, the poem "En Liliput". This fact proves that Tablada practiced haiku composition in a comprehensive 
way. In other words, as a poet-painter, he exercised haiku creation beginning the compositional process by either of the two involved dimensions: the image or the word. The manner in which he finally completed each piece of work -complementing one or the other compositional channel, depending on each particular situation- may have occurred sequentially or in a dialectic and simultaneous process -that is to say, first he finished the image and then he composed the poem or vice versa, or he kept going from one to the other in a fragmentary and intermittent way. On the other hand, the archive piece entitled Tres dibujos de frutas sobre charolas y dos bocetos (see image 8) includes what seem to be sketches of the images that would have appeared with several haikus.

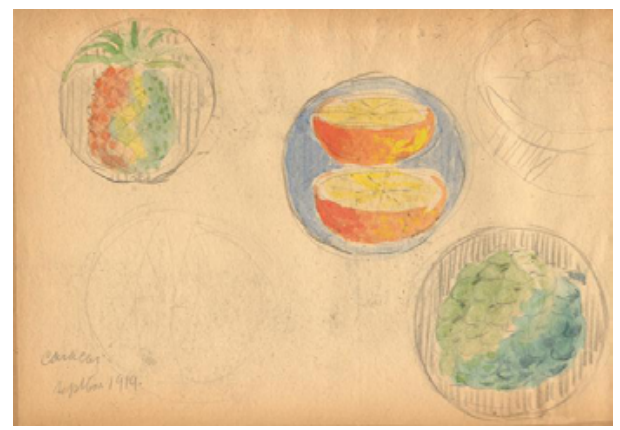

Image 8: Tres dibujos de frutas sobre charolas y dos bocetos.

Archivo José Juan Tablada

The haikus that finally appeared published were the following ones:

Frutas.

Sin amargura os cantará el poeta

Llevándose la mano a la cintura,

Oh frutas de mi dieta! ${ }^{4}$

4 Fruits. // With no grief the poet would sing / Putting his hand in his waist, / Oh fruits of my diet!

5 Soursop. // The breasts of the beloved / The lover of the tropics / Sees in your white pulp.

${ }^{6}$ Orange. // Give to my thirst / two golden cups / full of honey!

\section{Guanábana.}

Los senos de su amada

El amante del trópico

Mira en tu pulpa blanca. ${ }^{5}$

\section{Naranja.}

Dale a mi sed

Dos áureas tazas

Llenas de miel! ${ }^{6}$ 
It is of special importance to notice that in the haiku "Naranja", the literary image of the verse "dos áureas tazas" appears "translated" in the drawing, because the fruit has been cut by half.

Something similar takes place with the images Zoológico del Calvario, Un mono and Dos monos, that have a dialogue with the haiku "Un mono" (see images 9-11), because the animal is staring at the reader-observer.

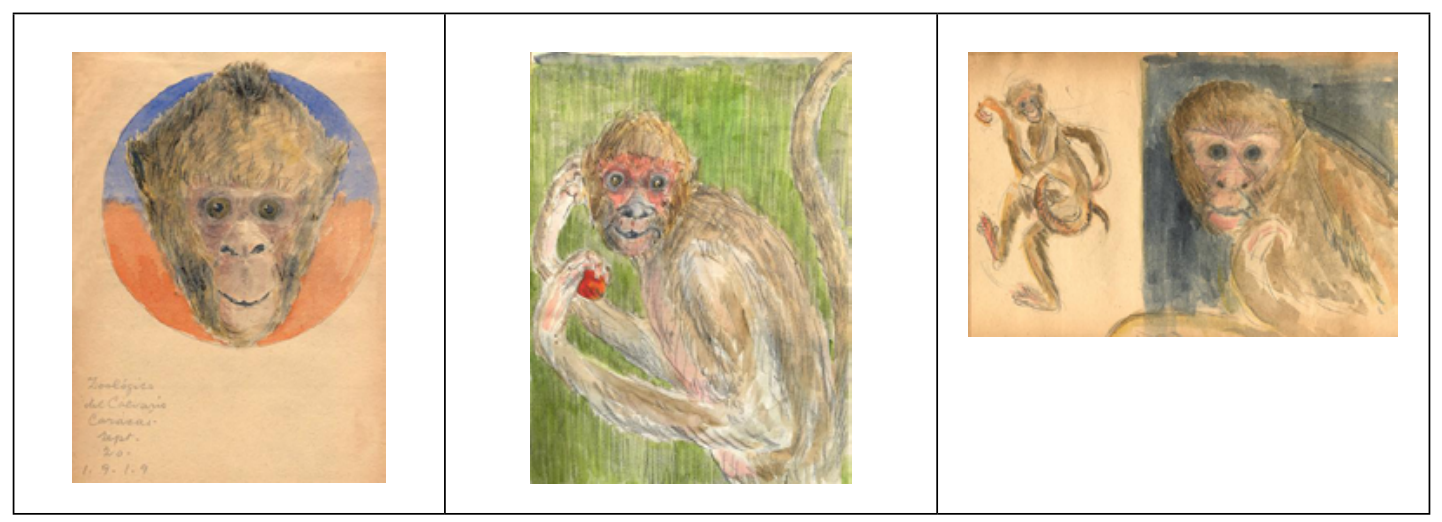

Images 9-11: Zoológico del Calvario; Un mono; Dos monos. Archivo José Juan Tablada.

\section{Un mono.}

El pequeño mono me mira...

¡Quisiera decirme

Algo que se le olvida!

${ }^{7}$ A monkey. // The little monkey stares at me... / He would like to tell me / Something he has forgotten!
Of the three images, I find that the first one is of singular importance. It appears inside a circle, in the same way as the ones that integrate Un dia... Poemas sintéticos. This happens also with the piece mentioned above Tres dibujos de frutas sobre charolas $y$ dos bocetos. All these images are evidence that $U n$ dia... Poemas sintéticos and El jarro de flores. Disociaciones líricas are really "twin books", as Tablada nicknamed them. The fact that $E$ l jarro de flores was finally illustrated with engravings of Adolfo Best-Maugard gives support to the theory that Tablada didn't have enough time to complete all the images or that he preferred someone else to do them, such as his friend, who was an established painter. This was not a simple whim. For sure Tablada was aiming at the possibility that the volume would be received in a better way by the critics and the public. 


\section{Support to clear up some information gaps in specific} periods of the life of Tablada and the context of his literary production. The first example of this type is due to a drug crisis that Tablada suffered in 1895. The information about this event was scarce and ambiguous, such as the article published by Carlos Díaz Dufoo (Revista Azul, September $15^{\text {th }}$ 1895), so frequently cited. The watercolors Tablada painted at the Hospital de San Hipólito constitute a dramatic testimony of an experience that, in other parts of his textual legacy, such as his Diario and the two volumes of his memoirs, was partially or totally silenced (see images 12-17).

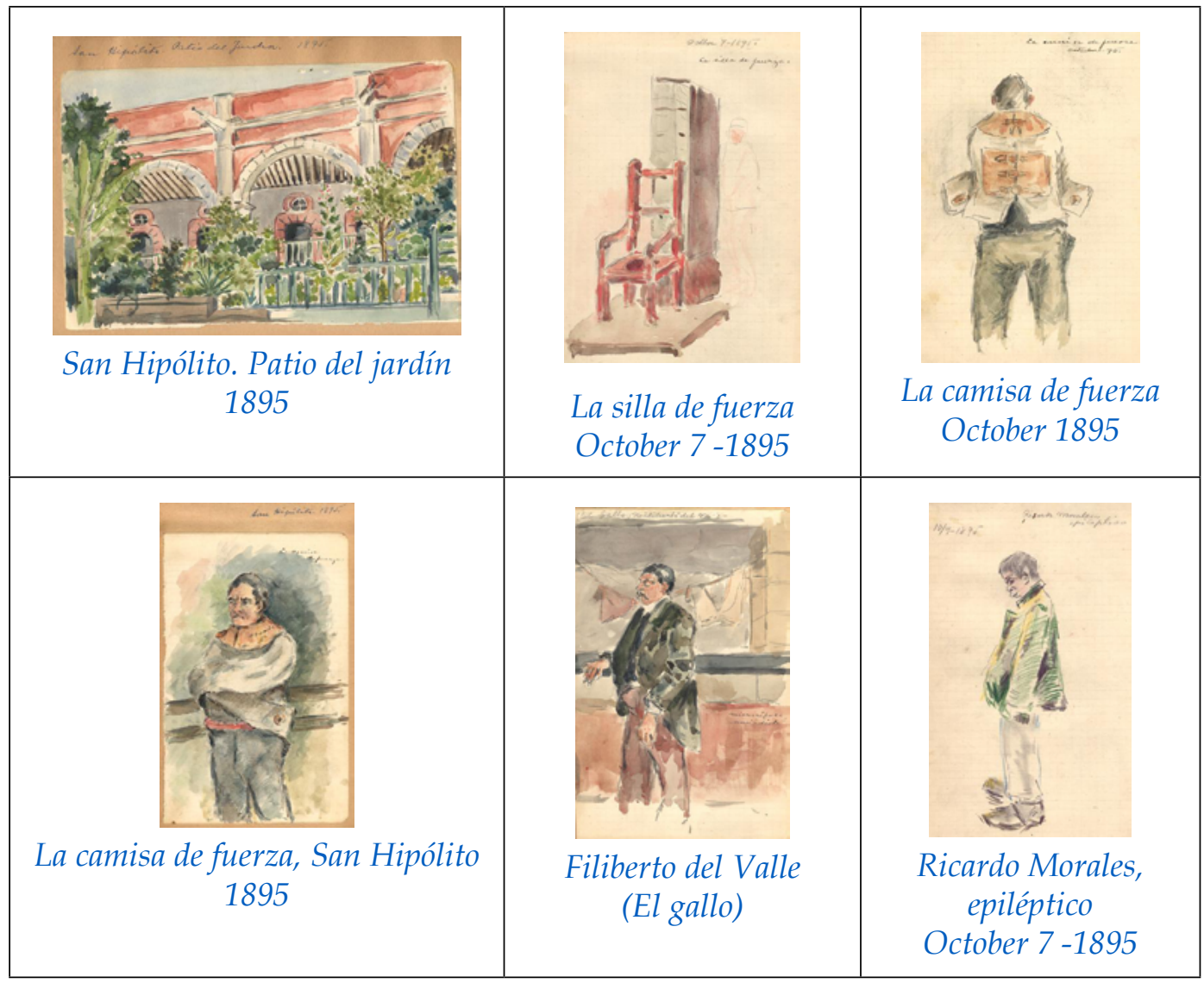

Images 12-17: San Hipólito. Patio del jardín 1895; La silla de fuerza October 7 -1895; La camisa de fuerza October 1895; La camisa de fuerza, San Hipólito 1895; Filiberto del Valle (El gallo); Ricardo Morales, epiléptico, October 7 -1895. Archivo José Juan Tablada. ${ }^{8}$

8 The images are commented in their c o r r e s p o n d i n g hyperlinks. 
${ }^{9} \mathrm{Cf}$. Anonimous, "En San Hipólito", El Tiempo, September $11^{\text {th }} 1895$, $p$. 3. The notice says: "D. José Juan Tablada, who was quite ill due to the abuse of morphine, decided, in a totally spontaneous way and advised by several friends, to put himself under treatment. With this purpose and for being essential to submit the patient to a special treatment that includes restraining him of his freedom of action, so that he can get by without the injections, the author resigned himself to remain for some time in the hospital for mentally deranged of San Hipólito, where he was lead by persons that appreciate him. Tablada occupies a special department, he is treated with all considerations and there is hope that he will be totally cured in a few weeks".

${ }^{10} \mathrm{C} \mathrm{f} . \quad$ "T or re s Palomar, orientalista kalogramático", El Mundo Ilustrado, January $18^{\text {th }} 1914$.

${ }^{11} \mathrm{E} 43^{\text {th }}$ st. Here I lived with Palomar in 1916 , the perfume laboratory; the only garlic soup, in the luxurious apartment. Mural kalogramas, the check for the roasted chicken, first ideographic verses. The dagger, Talon rouge and [illegible]
Only later it was possible to retrieve a small note, published with variations in newspapers such as El Tiempo or La Voz de México, saying that he was admitted in the Hospital de San Hipólito due to a morphine addiction. Following the council of his friends, he arrived to the hospital by his own will and stayed several weeks to avoid injecting himself again. ${ }^{9}$

Another nebulous period of Tablada's life starts in August 1914, when he fled to New York accused of collaborating with the dictatorship of Victoriano Huerta, and extends until October 1918, date in which he succeeds in getting reconciled with the government of Venustiano Carranza, marries Nina Cabrera and sails to South America, via La Habana, in an official diplomatic mission. For this period is of singular importance the newspaper clipping named Old Bartholomew's Church (see image 18) that has a handwritten note. It gives notice of his dwelling, in New York, with José Torres Palomar (ca.1873-1920), visual artist author of the kalogramas, a kind of monograms used mainly to mark personal objects, such as paper and envelopes for letters, pens, cufflinks, etc. Tablada wrote a review of Palomar's work with these artistic objects, in January 1914, while he was still in México. ${ }^{10}$ The handwritten note says: "E $43^{\text {th }}$ st. Aquí viví con Palomar en 1916, el laboratorio de perfumes; la única sopa de ajo, en el lujoso apartamento. Kalogramas murales, el cheque por el pollo asado, primeros versos ideográficos. El puñal, Talon rouge e [ilegible]"11 Besides the testimony of the frugality in the "luxurious apartment", the notice states that the "mural kalogramas" shared space with the poems "El puñal" and "Talon rouge", which later came to form part of Li po y otros poemas. Tablada didn't mention the kalogramas in his letter to Ramón López Velarde, where he answers the latter's doubts about ideographic poetry -an explanation that has been cited many times-, but this notice demonstrates that these artistic objects form part of the antecedents of his famous book, among others. In fact, the genealogy with which he dresses up the kalogramas, in his review, enriches the one he presents to López Velarde. 


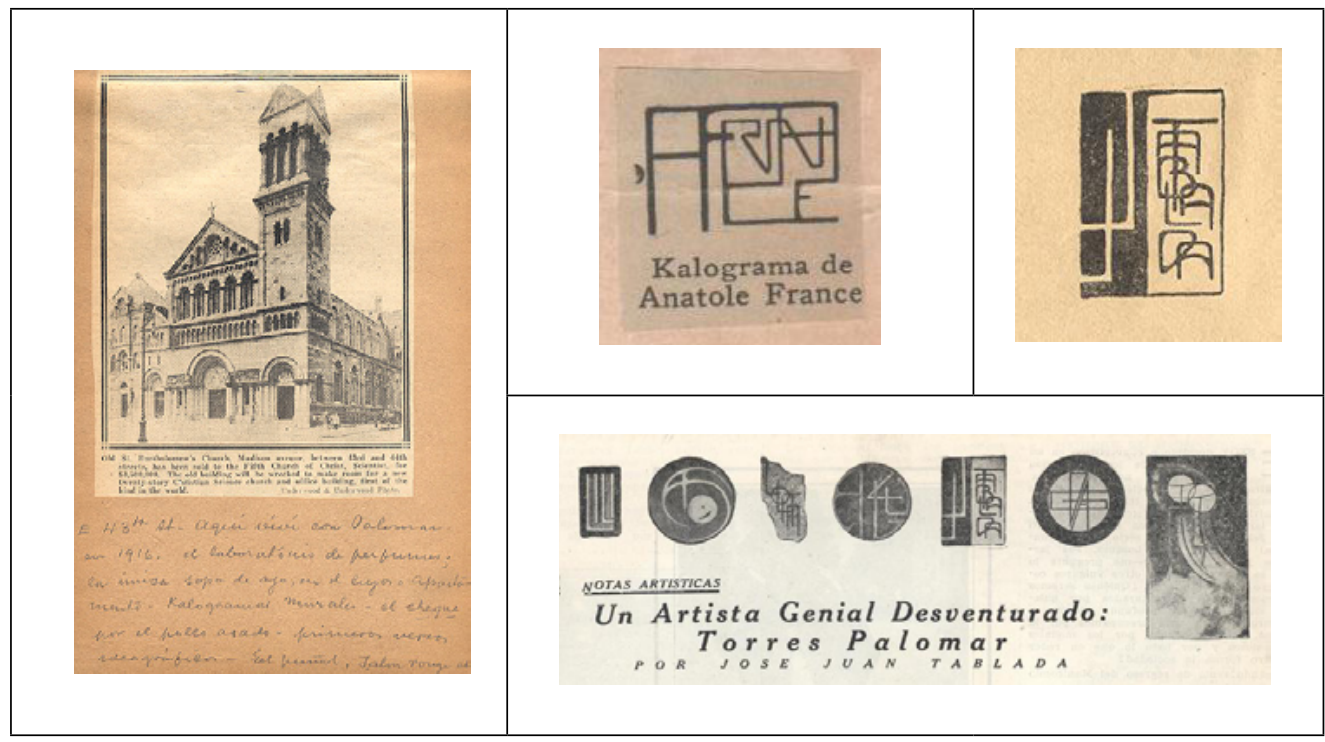

Images 18-21: Old Bartholomew's Church (Archivo José Juan Tablada); Kalograma of Anatole France (Archivo José Juan Tablada); Kalograma of Tablada (Detail from the front page of $A l$ sol y bajo la luna); Heading of the mourning chronicle "Un artista genial desventurado: Torres Palomar" with several kalogramas

(El Universal Ilustrado, March $\left.10^{\text {th }} 1921,25,54\right)$.

The curious phonetic coincidence between "caligramme" and "kalograma" has produced a double effect: on one hand, it opens a suspicion crack in the originality of Tablada, because it makes him target of those who light-mindedly subordinate his ideographic poetry to Apollinaires's calligrammes. On the other hand, after checking that Tablada reviewed the kalogramas of Torres Palomar, in January 1914, while Apollinaire published "Lettre Océan", his first caligramme, in Les Soirées de Paris, in June 1914, the suspicion of an epigonous behaviour vanishes. Tablada could not have previously heard about caligrammes as such because the neologism is attributed to Apollinaire and must have appeared after his first composition on this genre. In his article, Tablada credits Palomar of having invented the term "kalograma", so in any case, Tablada's debt is with his friend. It is important to emphasize that the "kalograma" is not a poem but an artistic object. Nevertheless, this does not discard that Tablada could have known some of the Futurist visual poems, and the controversies between Cubists and Futurists in Paris, through the novelties which were published in reviews and newspapers at the time. This possibility is often 
${ }^{12}$ In the electronic version of Un día... Poemas sintéticos this peculiarity was not reproduced in the presentation of each of the "pages". A facsimilar edition has been published recently: José Juan Tablada, Un día... Poemas sintéticos. México: Consejo Nacional para la Cultura y las Artes, 2008, 104 pp. forgotten or set aside without considering how well informed were the Latin-American poets about what was taking place in Europe, specially in France.

\section{The importance of objects such as the Japanese stamps, the kalogramas and the ex-libris, in Tablada's trajectory. As I} mentioned in the essay "José Juan Tablada: la escritura iluminada por la imagen", these three types of objects are closely related and converge in Tablada's artistic practice. Connoisseur of Japanese culture, the poet was familiarized with ukiyo-e prints and with the use of personalized stamps by the artists involved in their production. As he explains and also illustrates in his book on the painter Hiroshige, in the prints appeared stamps and signatures of authors, engravers and censors. Emulating these practices insofar as it was possible, Tablada used in Hiroshigué... a monogram and a stamp similar to the Japanese ones. The stamp was much like the kalograma that Torres Palomar made for him and that was included in Al sol y bajo la luna. Which of the two would have been created first, the kalograma or the "Japanese" stamp? We don't know. What we know for sure is that Tablada used the monogram in Un día... poemas sintéticos in a similar way as he did in Hiroshigué..., to give a personal touch to the pages, indicating poetic or editorial authorship. He even incorporated it as a graphic theme for the cover. ${ }^{12}$ Tablada also used this stamp to sign watercolors (for example the piece Oncidium tigrinium), and as ex-libris, in some of the volumes of his personal library that today are scattered in the general collection of the Biblioteca Nacional. Also the other ex-libris that is registered in the graphic archive under the title Dos ex-libris is important (even though the title mentions "two ex-libris", the object is the same, only in different stages of its production) because its oriental features are not a mere coincidence, they follow the same idea and taste. 


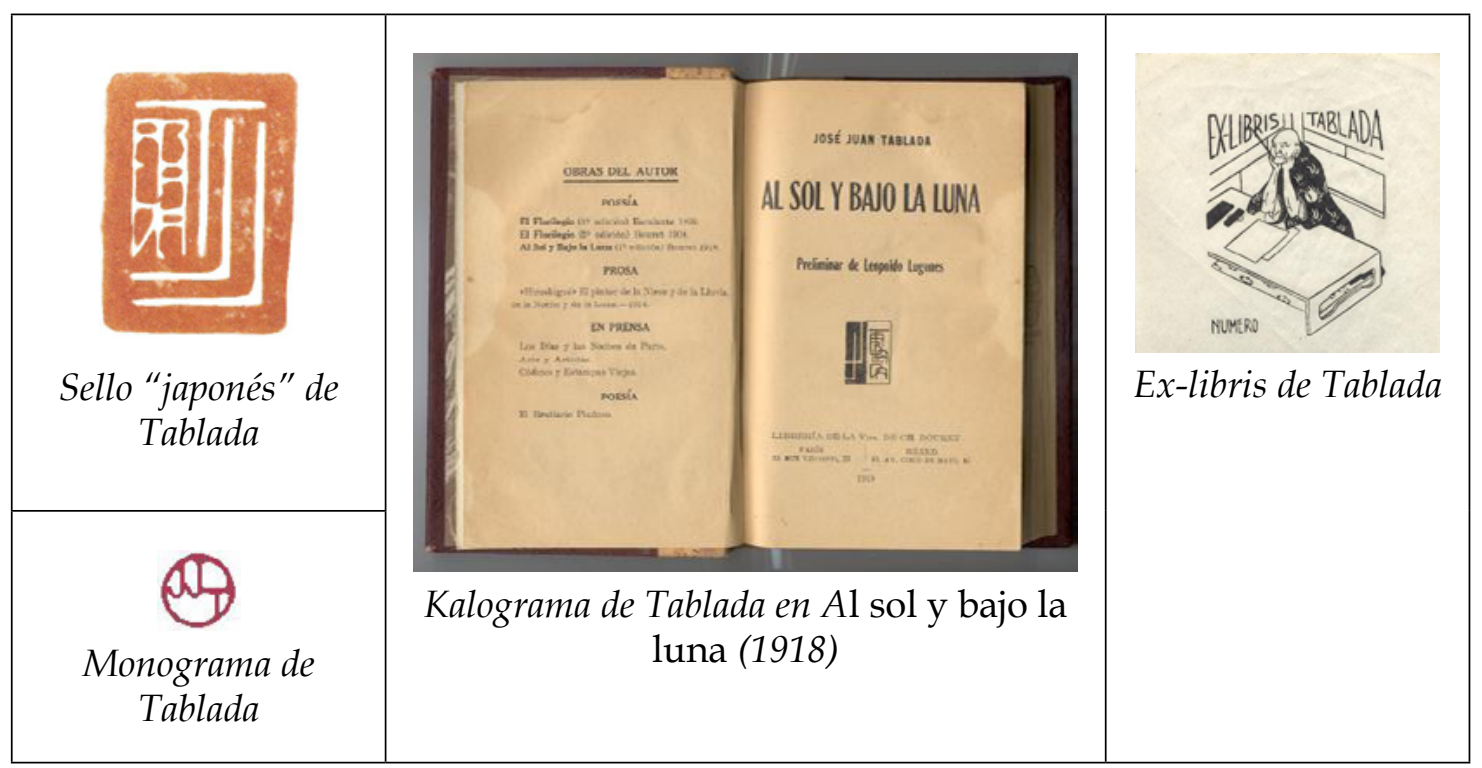

Images 22-25: "Japanese" stamp of Tablada; Kalograma of Tablada in Al sol y bajo la luna (1918); One ex-libris of Tablada; Monogram of Tablada.

Two specific events that recently woke up in me the awareness that, along the whole process of annotating the graphic archive and of constructing the CD-ROM, a new reading practice had been gestated, were: the reading of the book How We Think. Digital Media and Contemporary Technogenesis (2012), by N. Katherine Hayles, and the encounter with a curious detail in the cover of Al sol y bajo la luna (1918). This detail is another result of Tablada's graphic culture, this time related with the pictographic writing in the Prehispanic codices, that presented complex symbologies, as enigmatic and luring as the Egyptian hieroglyphs. In the Archivo General de la Nación is documented that Tablada was professor of Archeology in the Museo Nacional, from 1906 to 1910, and several pieces of his graphic archive and annotations in his Diario serve as proofs of his interests in those areas, such as the drawings Dos máscaras prehispánicas and Catálogo de malacates. In the cover of $\mathrm{Al}$ sol y bajo la luna (see image 26), the pictograms of both celestial bodies can be clearly identified: 


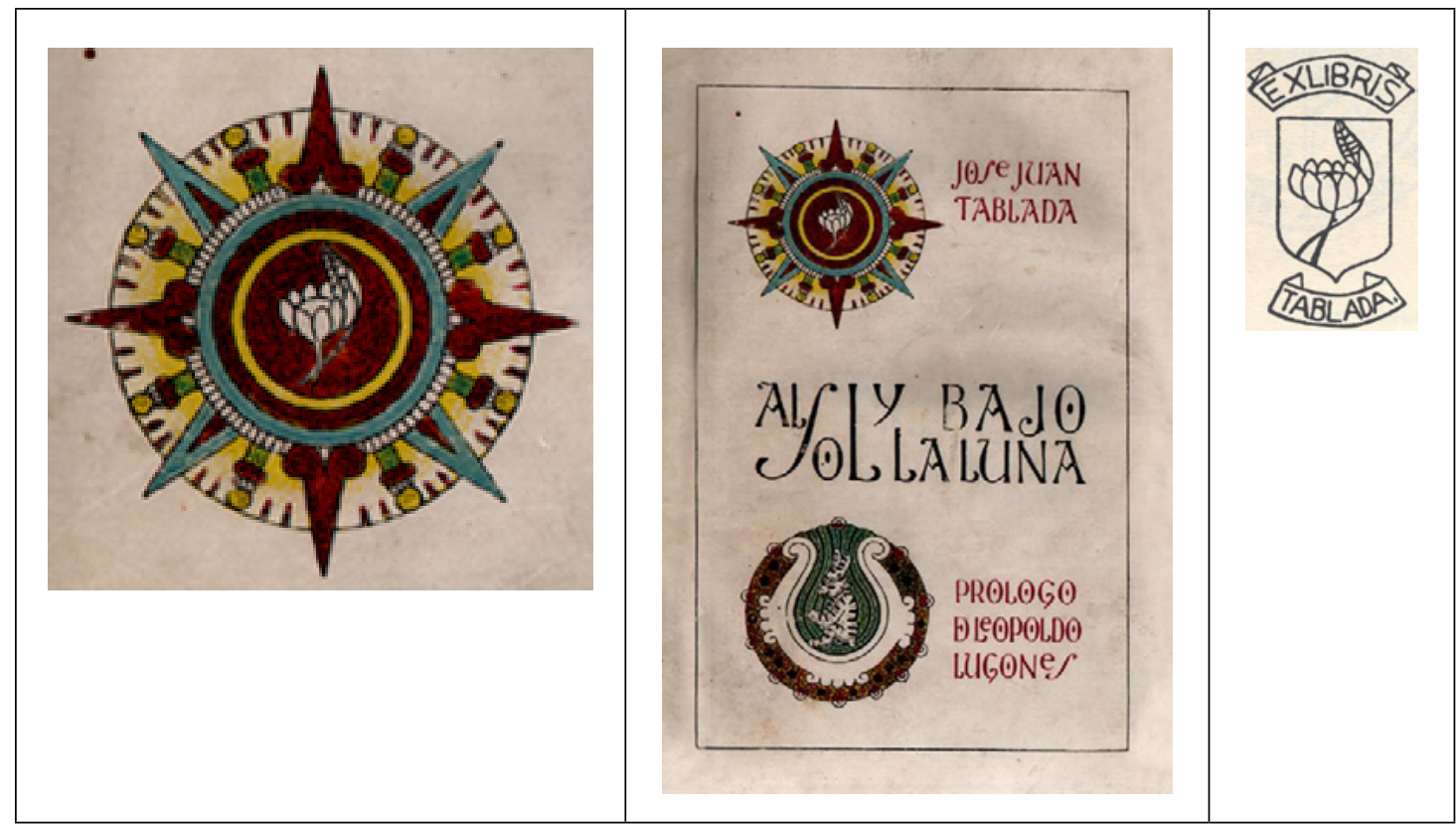

Images 26-28: Cover of Al sol y bajo la luna (1918); Detail of the cover of Al sol y bajo la luna (1918); Ex-libris of Tablada ca. 1900.

Inside the one that represents the Moon, the rabbit of the traditional pre-hispanic legend can be found, but inside the one that corresponds to the Sun, I saw a figure that seemed to me enigmatic but nevertheless familiar (see image 28). Where did it come from? My memory was not able to identify in which place I had seen it. It resembled the silhouette of the lotus in the Japanese iconography and this lead me to ask my friend Amaury García - japanist dedicated to the study of the ukiyo-e who had contributed in the task of cataloguing Tablada's collection of Japanese prints - if he recognized it. He agreed with me that it looked like a Japanese lotus but he couldn't identify what was the small object that emerged to the right. For some days I remained with the burning doubt when, at last, the mentioned page Dos ex libris of the electronic version of Tablada's graphic archive appeared. To annotate this image, as members of the annotation team, we had used the book $E x$ libris mexicanos. Artistas del siglo XX (2001), by Selva Hernández López and Mercurio López Casillas, where we found another of Tablada's ex-libris with the same image of the lotus slightly modified (see image 28) and we had included it. In that moment 
I realized that it was quite possible that the image represented a stylized fusion of a lotus with a corn ear, a hybrid image that referred to the idea of the cultural fraternity between America and the Orient or between México and Japan. Among Tablada's unfulfilled literary projects figured a book of essays that would be entitled "De aztecas y japoneses", in which he would capture the similarities he found between both nations, resemblances that appear scattered in chronicles such as "Los funerales de un noble", collected in En el país del sol, or in the book Hiroshigué..., in the chapter dedicated to comment the "Meisho Yedo Hiakkei" [One Hundred Famous Views of Edo].

This sudden discovery, that had now the features of novelty (in the annotation process back in 2003 I was not aware of the fusion lotus-corn ear and of its possible cultural meaning), was telling me that the annotation process with the images had built in my memory an index based on them that was linked with different episodes of Tablada's biography. For example, the year 1916 puts in my mind the clipping Old Bartholomew Church and, for sure, if the mentioned church still exists and if someday I get to see it, I will undoubtedly remember Tablada and his poems "El puñal" and "Talon rouge", and also Torres Palomar and his kalogramas. Would it be exaggerated to say that for me -following more or less the formulations of Luz Aurora Pimentel- any biographic narrative of Tablada, written already or to be written in the future, becomes an iconotext? ${ }^{13}$ The presence in my memory of the images of the graphic archive created an unavoidable chronological sequence when I thought about the episodes of Tablada's life?

The other event that I mentioned is the reading of How We Think (2012), by N. Katherine Hayles, specifically the chapter "How We Read", in which the author compares and discusses three modalities of reading: close, hyper and machine reading. Hayle's book is focused on what today is known as "Digital Humanities", a research field that is rapidly developing and that addresses humanistic practices associated with computer techniques, a symbiosis that reaches far out from the printed universe. In that field, Hayles places issues that go from the digital editions of printed texts to the historic research that recreates, for example, architectural environments through techniques of virtual reality. In the traditional humanities, 
reading is associated with the paradigm of close reading, that comes from the field of literary studies and that was adopted by them as an identity profile centered in the detailed analysis of texts and not of contexts; that is to say, in the examination of what is written and its textual and rhetorical mechanisms, and not of what surrounds what is written: its history, philosophy, psychology, sociology, etc. The inclusion of study objects whose "literary" identity was questionable, or that demanded skills located out of the world of the strictly textual, always caused resistance. Then close reading became an ideology that also discriminated the production that was located out of the printed world, for example the digital production. At the same time, the growth of the literary production and the updating of diverse canons exacerbated the crisis of close reading due to the evident impossibility of reading everything in the prescribed meticulous manner. To relieve this crisis, some proposals have emerged, such as the distant reading of Franco Moretti -also commented by Hayles - that points out distance and mediation (the consideration of the acquisition of knowledge through partial approximations or through researches made by other readers) as the basis of broader perspectives of the development of a "world literature". Moretti's proposal reminds me of another very interesting one made by Pierre Bayard, in his amusing but serious book Comment parler des livres que l'on n'a pas lu (2007), where he discusses the exaggerated prejudices against incidental or partial readings, and the real problems in the reading exercises results, such as the caducity of memory, the errors of one's own reading and interpretation. For that reason, the chapter entitled "Ways of avoiding reading" is subdivided in: "Books we don't know", "Books we glance through", "Books we have heard of", “Books we forget". ${ }^{14}$ Borges had already commented on the virtues of book's summaries and even wrote some summaries of inexistent books to include them in his stories - and Macedonio Fernández had theorized about the "lector salteado" [jumping reader].

To comment the hyper reading, Hayles cites James Sosnoski, among others, who, in 1999, defined this practice as "readerdirected, screen-based, computer-assisted reading". Hyper

${ }^{14}$ Cf. Pierre Bayard, Como falar dos livros que não lemos?, pp. 21-68. reading includes the use of searching engines, such as Google, the screening via key-words, the skimming or scanning (quick 
reading that focuses on the main ideas of a text, supposedly localized in the first sentences of each paragraph or in the initial and final paragraphs), the jumping through hyperlinks, the copy of fragments of texts and of images, the text search in pages, etc. There is strong evidence, Hayles comments, that this type of reading differs substantially from close reading or, making a pun with the term, closed reading. On the other hand, she also points out that there is a lot of controversy around this new form of reading as opposed to concentration and memory, an issue addressed in a shocking manner in the book The Shallows: What the Internet is Doing to Our Brains (2010), by Nicholas Carr. As for Carr's point of view, Hayles remains on wait of more solid information, questioning the "threat" denounced by Carr, revealing the bias of some of his interpretations of tests made with magnetic resonances of the brain, and warning that it is too early to make a summary judgment of hyper reading.

In the case of machine reading, Hayles acknowledges its superiority over the unavoidable error and/or bias of interpretation carried by the reading made by human beings. The idea behind machine reading is the automation that produces, with the aid of a computer, textual maps, statistics and even assemblies and other type of manipulations, especially those made over large masses of text. Hayles locates the legitimacy of this type of reading, in principle not human, as a "step forward" on the hypothetical extreme situation of distant reading, in which information is obtained out of texts without recurring to them directly, not even in a small proportion. These ideas reminded me, of course, of the CD's with Tablada's chronicles, as a simple example: a database is a machine reading aid capable of producing certain prestructured indexes defined by specific parameters operated by a search engine. Another more sophisticated version of the machine reading can be visualized in the reading system Poesía Densa, developed by Diego Bonilla. Soon this system will have an update that will include a traditional index, useful to read the corpus of Tablada's poetic works in an ordered common manner (by books and chapters), and another index by words that helps to better appreciate the vocabulary contained in the corpus. 
To conclude I want to mention that, after the construction of the webpage José Juan Tablada: letra e imagen and the publishing of its corresponding CD-ROM, several studies related to the visual dimension of the artistic trajectory of Tablada have appeared. That is the case of José Juan Tablada: su haikú y su japonismo, by Seiko Ota, that made the most of the images of our CD-ROM and of some of the critical appraisals included with them; or the "Prólogo" to the anthology José Juan Tablada, by the historian Antonio Saborit, in which the image "Old Bartholomew's Church" has an important role to establish the contact that Tablada had with Marius de Zayas and José Torres Palomar in New York. It seems to me that it's almost sure that the narration of this experience with the genesis of hyper reading on the life and works of Tablada, after having carried out the mentioned digital projects, can establish a dialogue with the experiences of both researchers. In the Instituto de Investigaciones Filológicas, where the graphic archive is deposited, we receive an annual average of three to four requests to use the images that were exposed publicly for the first time in the webpage José Juan Tablada: letra e imagen. Perhaps the most exciting and surprising fact of the personal experience I have just described is the confirmation that practice constructs the basis of theory: hyper reading and machine reading had not reached our ears as concepts, even though in our practice we were exercising them, without noticing it, through reading and writing modalities that were very similar. The front door to the awareness of this experience was to be found in the mnemonic structure modifications that became patent and clear in the process of recollection, demonstrating that the digital humanities have a future far beyond the universe of books and paper but always connected to them in some way.

\section{BIBLIOGRAPHY}

BAYARD, Pierre. Como falar dos livros que não lemos? Trad. Rejane Janowitzer. Rio de Janeiro: Objetiva, 2007.

CARR, Nicholas. The Shallows: What the Internet is Doing to Our Brains. London: Atlantic Books, 2010. Kindle Edition. 
HAYLES, N. Katherine. How We Think: Digital Media and Contemporary Technogenesis. Chicago and London: The University of Chicago, 2011. Kindle Edition.

HERNÁNDEZ LÓPEZ, Selva; Mercurio LÓPEZ CASILLAS. Ex-libris mexicanos. Artistas del siglo XX. México: Editorial RM, 2001.

Horizonte de poesía mexicana. Ed. Gustavo Jiménez Aguirre y Rodolfo Mata. México: UNAM, 1996.

OTA, Seiko. José Juan Tablada: su haikú y su japonismo. México: Fondo de Cultura Económica, 2014.

PIMENTEL, Luz Aurora. Ecfrasis y lecturas iconotextuales. Poligrafías, México, UNAM, n.IV, p. 205-215, 2003.

TABLADA, José Juan. La Babilonia de Hierrro. Crónicas neoyorquinas (1920-1936). Coordinación de Rodolfo Mata Sandoval. Estudio preliminar de Esther Hernández Palacios. México: Centro de Estudios Literarios, UNAM / CENEDIC, Universidad de Colima / CONACYT, 1997. CD-ROM, 725 crónicas publicadas en diferentes diarios. (Crónica general de José Juan Tablada, volumen 1)

Colección de estampas japonesas de José Juan Tablada en la Biblioteca Nacional. Org. y coord. R. Mata. México: UNAM / Biblioteca Nacional / CONACYT / Japan Foundation, s/d.

José Juan Tablada. Selección y prólogo de Antonio Saborit. México: Ediciones Cal y Arena, 2008, 849 p. Colección Los Imprescindibles.

José Juan Tablada: letra e imagen (poesía, prosa, obra gráfica y varia documental). Coordinación de Rodolfo Mata. México: Centro de Estudios Literarios, UNAM / CONACYT, 2003. CD-ROM.

México de día y de noche. Crónicas mexicanas (1928-1944). Coordinación de Rodolfo Mata Sandoval. Estudio preliminar de Pilar Mandujano Jacobo. México: Centro de Estudios Literarios, UNAM / CENEDIC, Universidad de Colima / CONACYT, 1998. CD-ROM, 395 crónicas publicadas en diferentes diarios. (Crónica general de José Juan Tablada, volumen 2) 
TABLADA, José Juan. En el país del sol. Ed., pról. y notas Rodolfo Mata. México: UNAM / CONACYT, s/d.

Al sol y bajo la luna. Nota preliminar de Leopoldo Lugones, portada de Jorge Enciso, kalograma de Torres Palomar. París-México: Librería de la Viuda de Ch. Bouret, 1918, 240 p. 


\section{Resumo}

\section{José Juan Tablada Digital e a gênese de uma hiperleitura}

O presente artigo descreve o modo como o desenvolvimento de dois projetos digitais envolvendo as obras do poeta mexicano José Juan Tablada afetaram a natureza das práticas de leitura e escrita do autor e de outros integrantes da equipe de pesquisa. O primeiro projeto, levado a cabo em 1997 e 1998, compreende dois CD-ROM com duas importantes coletâneas de crônicas jornalísticas: La Babilonia de Hierro. Crónicas neoyorquinas (1920-1936) (724 crônicas) e México de día y de noche. Crónicas mexicanas (1928-1943) (399 crônicas). O segundo resultou em outro CD-ROM, José Juan Tablada: letra e imagen (poesía, prosa, obra gráfica y varia documental) (2003), o qual incluiu o arquivo gráfico de Tablada, seus quatro livros de poesia visual e outras obras envolvendo a relação entre palavra e imagem. O projeto inclui também uma página web (wwww.tablada.unam.mx). O autor observa como as buscas automáticas de texto, possibilitadas pelo primeiro $C D$, ajudaram no processo de anotação das peças do arquivo gráfico - o qual compreende aquarelas, desenhos a lápis, carvão e caneta, fotografias e recortes de jornais e revistas -, e o modo como a observação minuciosa dessas imagens revelou informação relativa à vida e obras de Tablada. Essa informação tinha sido desestimada porque as peças do arquivo tinham sido consideradas quase exclusivamente em sua dimensão visual mais do que em relação com o campo literário. $O$ autor discute as três modalidades de leitura - close, hyper e machine reading - propostas por N. Katherine Hayles em How We Think (2012), e mostra como os projetos de pesquisa digital de Tablada envolvem a prática das duas últimas modalidades de um modo natural e imperceptível. O conjunto da experiência demonstrou também que a hiperleitura promovida pela construção da página web resultou em mudanças mnemónicas que ligaram as imagens do arquivo gráfico com o discurso biográfico de Tablada.

Palavras-chave: Humanidades digitais, literatura latino-americana, poesia mexicana, poesia visual 